\title{
Yield, Shoot and Root Growth, and Physiological Responses of Mature Peach Trees to Grass Competition
}

\author{
Thomas J. Tworkoski and D. Michael Glenn \\ Appalachian Fruit Research Station, U.S. Department of Agriculture, \\ Agricultural Research Service, Kearneysville, WV 25430
}

Additional index words. Prunus persica, yield efficiency, pruning, root density, leaf water potential, leaf nitrogen, Festuca arundinacea, Lolium perenne, Agrostis gigantea, Dactylis glomerata, Phleum pratense, Bromus carintus

Abstract. Competitive effects of different grass species were evaluated on growth, yield, leaf N, and leaf water potential of 8-year-old peach [Prunus persica (L.) Batsch.] trees and on weed abundance. Two cultivars ('Loring' on Lovell rootstock and 'Redhaven' on Halford rootstock) of peach trees were planted in separate orchards in 1987. Nine orchard floor treatments were installed beneath the peach trees in 1995: Festuca arundinacea Schreber (tall fescue); Lolium perenne L., var. Manhattan II (perennial ryegrass); Lolium perenne L., var. Linn; Agrostis gigantea Roth (red top); Dactylis glomerata L. (orchardgrass); Phleum pratense L. (timothy); Bromus carinatus Hook. and Arn. (brome); weedy control; and herbicide weed control (simazine, glyphosate). In general, grasses reduced vegetative growth and yield in both cultivars. Orchardgrass was one of the most competitive species and reduced vertical water sprout length by $15 \%$ to $27 \%$ and lateral shoot length on fruit-bearing branches by $19 \%$ to $30 \%$ compared with herbicide treatments. Orchardgrass reduced yield by $37 \%$ and $24 \%$ in 'Loring' and 'Redhaven', respectively. All grasses were not equally competitive; 'Linn' perennial ryegrass did not significantly reduce growth or yield in 'Redhaven'. Control treatments with weeds also did not differ from herbicide treatments in peach tree growth and yield. Grass and weed ground covers consistently reduced peach tree leaf $\mathbf{N}$ by at least $10 \%$, compared to herbicide treatment, possibly due to reduced root growth. 'Redhaven' root density in the top $10 \mathrm{~cm}$ of soil was $\approx 12 \mathrm{~cm} \cdot \mathrm{cm}^{-3}$ in herbicide strips $\mathrm{vs.} 1 \mathrm{~cm} \cdot \mathrm{cm}^{-3}$ in weedy or ground-covered strips. Peach leaf water potential was not affected by grass and weeds. Weed weights were significantly reduced by all grasses compared with weedy control. The results indicate that peach cultivars respond differently to grass competition, but the relative competitiveness of each grass species was similar for both cultivars. Grass competition reduced growth, yield, and pruning weights of mature peach trees, but the reduction in vegetative growth did not significantly reduce pruning time per tree. Grasses that are less inhibitory to peach yield may be useful for weed management in orchards.

Peach tree size is managed to maintain productivity and to facilitate cultural and harvest operations in the orchard. Currently, no size-controlling rootstocks are available for peach, and trees are pruned to maintain the desired size. Annual pruning is a significant expense and the numerous cuts may provide entry for disease (Hayden and Emerson, 1975).

Peach tree size can be restricted by tall fescue competition, and pruning weights per tree were reduced in trees grown continuously with grass after planting (Glenn and Welker, 1996). Vegetative growth control of established peach trees through grass competition has been inconsistent. For example, annual ryegrass (Lolium multiflorum Lam.) beneath 5- to-7-year-old peach trees reduced pruning weights in only one of three years (Huslig et al., 1993). It is possible that interspecific competition will vary among different grass and fruit species (Shribbs et al., 1986).

Complete sod covering an orchard floor can be extremely debilitating to fruit tree vigor

Received for publication 11 Dec. 2000. Accepted for publication 21 May 2001.
(Hogue and Neilsen, 1987). Haynes (1980) and Bedford and Pickering (1919) reported that fruit tree vigor decreased in proportion to the depth of grass root development. Grasses exert competition by withdrawing moisture from the soil and creating greater soil moisture deficits (Atkinson and White, 1981) or by competing for $\mathrm{N}$ (Haynes, 1980).

Few studies have evaluated the relative competitiveness of different grass species on nutrient and water uptake in fruit trees. Butler (1986) reviewed numerous grass species used for horticulture plantings, concluding that orchardgrass, timothy, and smooth bromegrass (Bromus unarms Lees.) were vigorous and could be used for traffic corridors. Tall fescue was also a good travel alley grass, but it could extract soil moisture to a depth of 105 $\mathrm{cm}$ and therefore compete with fruit trees for moisture. Hogue and Neilsen (1987) reported that perennial ryegrass formed a deep-rooted sod that removed soil moisture necessary for high fruit tree vigor. Relative competitiveness between equal stand densities of different ground cover species on 'Smoothee' apples (Malus $\times$ domestica Borkh.) was linked to dif- ferences in grass biomass production (Shribbs et al. 1986). Thus, grass competitiveness with fruit trees has been related to root characteristics and to shoot biomass or growth rate.

Although interspecific competition is expected, grass may enhance or maintain soil quality by providing a pool of minerals in organic matter, and by increasing water penetration after rain (Atkinson and White, 1981; Haynes, 1980). Grass also may improve orchard growing conditions by reducing weed growth. Broadleaved weeds can reduce pollination and host viruses and nematodes that injure fruit trees (Merwin and Stiles, 1998). It may be possible to manage the composition of the weed community by reducing flowering weeds with competitive grass. Thus, grass cover of orchard floors may have beneficial impacts by enhancing soil quality and reducing targeted weeds. Reduced peach tree vigor from grass competition could also be beneficial provided that savings in tree pruning or weed control counterbalanced losses in yield.

Competitive attributes of different grass species and mature peach trees are not well established, but could affect orchard floor management practices. The objectives of this research were to: 1) determine the effect of seven species of grass on growth, leaf nitrogen concentration, leaf water potential, and yield of 8-year-old peach trees; and 2) determine the effect of seven grasses on weed abundance in peach orchards.

\section{Materials and Methods}

Orchard. Two peach cultivars ('Loring' on Lovell rootstock and 'Redhaven' on Halford rootstock) were planted in separate orchards in Apr. 1987 with a $4.5 \times 4.5-\mathrm{m}$ spacing at the Appalachian Fruit Research Station near Kearneysville, W.Va. Soil was Hagerstown silt loam (fine, mixed Mesic Typic Hapludalf). The trees were pruned to an open center and grown for 8 years in 2.4-m vegetation-free strips with tall fescue ('Kentucky-31') grass alleys between tree rows. Weeds were controlled with $1 \mathrm{~kg} \cdot \mathrm{ha}^{-1}$ diuron $\left[N^{\prime}-(3,4-\right.$ dichlorophenyl)- $N, N$-dimethylurea] and 1 $\mathrm{kg} \cdot \mathrm{ha}^{-1}$ terbacil[5-chloro-3-(1,1-dimethylethyl)6-methyl-2,4(1H,3H)-pyrimidinedione], applied each May.

In previous greenhouse experiments we screened 99 possible ground covers (Tworkoski and Glenn, 1996), and seven of the most vigorous were selected to be grown with the peach trees. Grass was planted under peach trees in May 1995 as single-tree plots. Nine orchard floor ground covers were installed as treatments: 'Kentucky-31' tall fescue; 'Manhattan II' perennial ryegrass; 'Linn' perennial ryegrass; 'Streaker' red top grass; 'Benchmark' orchardgrass; 'Clair' timothy; 'Matua' brome grass; weedy control; and herbicide control. Red top grass was sown at a rate of 44 $\mathrm{kg} \cdot \mathrm{ha}^{-1}$. The other ground covers were sown at a rate of $88 \mathrm{~kg} \cdot \mathrm{ha}^{-1}$. Herbicides were simazine (6-chloro-N,N'-diethyl-1,3,5-triazine-2,4diamine, applied at $1 \mathrm{~kg} \cdot \mathrm{ha}^{-1}$ each May) and spot-treatments with glyphosate $[N$ (phosphonomethyl) glycine]. Herbicide- 
treated plots were $2.4-\mathrm{m}$ wide $\times$ 4.5-m long with the tree in the center of the plot. Weedy control plots contained various species of native plants such as: common dandelion (Taraxacum officionale Wigg.); white clover (Trifolium repens L.); yellow woodsorrel (Oxalis stricta L.); large crabgrass [Digitaria sanguinalis (L.) Scop.]; broadleaf plantain (Plantago major L.); and poison ivy [Toxicodendron radicans $(\mathrm{L}$.) Kuntze]. All plots were mowed once to a height of $12 \mathrm{~cm}$ during the growing season and at the end of each season after ground cover measurements were taken.

Experimental design. The two orchards were treated as two experiments. Each experiment was a randomized complete block in a split-plot design with grass as a main effect and time as the subplot factor. An experimental unit (plot) consisted of one tree, and each grass treatment was replicated five times. Significant treatment and year effects occurred, but treatment $\times$ year interactions were nonsignificant. Therefore, responses were presented as the average over years. Means were separated with Bonferroni (Dunn) $t$ test (SAS Institute, 1994). Pearson coefficients were calculated to evaluate relationships among peach tree and ground cover variables.

Shoot and root growth. At the end of the growing seasons in 1995, 1996, and 1997, the annual vegetative growth was measured. Lengths and weights of three of the largest, most vigorous 1-year-old vertical shoots ("watersprouts") from main scaffold branches were measured on each tree. Lengths and weights of three representative 1-year-old lateral shoots per tree were also measured. Lateral shoots were from the outer perimeter of the canopy and grew from fruit-bearing branches. Time to prune each tree was measured during winter pruning and all pruned branches from each tree were collected and weighed each year. For consistency, one person pruned all trees each year.

At the end of the 1998 growing season, three soil cores per single-tree plot $(5 \mathrm{~cm}$ in diameter) were collected and separated into two fractions (0- to $10-$ and $10-$ to $20-\mathrm{cm}$ depth) and pooled by depth. Soil cores were collected from different, randomly selected quadrats at a distance $\approx 1 \mathrm{~m}$ from the tree trunk. Soil was washed from the roots and peach roots were separated from grass and weed roots. Roots were photographed, their lengths measured using a Computer Image Analysis System (CID, Vancouver, Wash.), and weighed. Calculated values were root density ( $\mathrm{cm}$ root length $\cdot \mathrm{cm}^{-3}$ soil volume) and specific root length (SRL, cm root length. $\mathrm{gm}^{-1}$ root weight).

Yield. Fruit were hand picked in two or three pickings each year (1995 through 1998) when they were judged mature using commercial standards. Number and weight of fruit from each tree were measured for three diameter size classes: $<50.8 \mathrm{~mm}$, between 50.8 and $63.5 \mathrm{~mm}$, and $\geq 63.5 \mathrm{~mm}$. Yield efficiency was calculated as the fruit weight divided by trunk cross-sectional area (tcsa) $30 \mathrm{~cm}$ above the bud union.

Physiological indices. Leaf water poten-
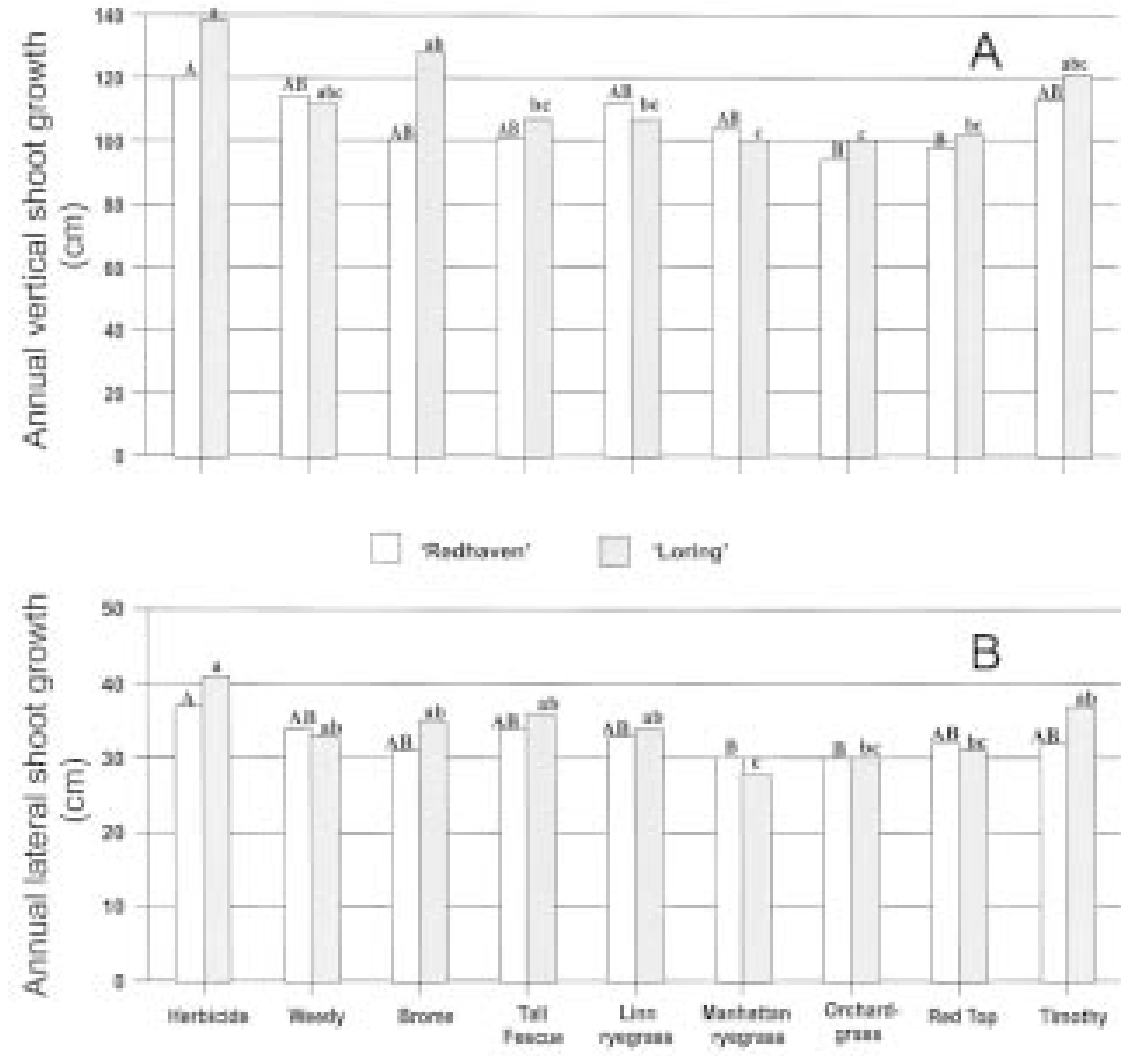

Fig. 1. Average annual growth (1995-97) of (A) vertical shoots and (B) lateral shoots from the edge of the canopy for mature 'Loring' and 'Redhaven' peach trees grown with ground cover competition. Within each cultivar, bars with the same letter do not differ at $P \leq 0.05$.
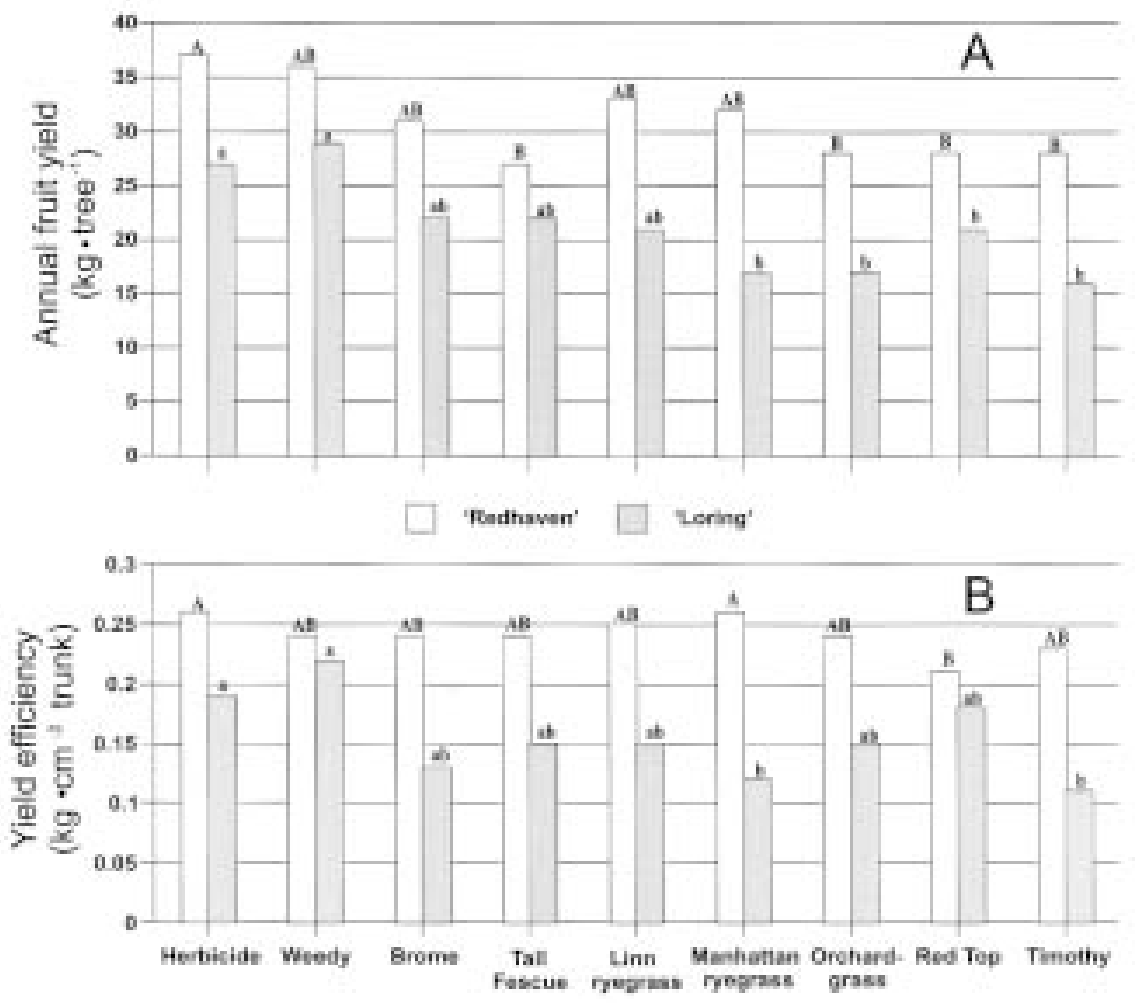

Fig. 2. Average annual weight of (A) all fruit and (B) of yield efficiency per tree (1995-98) for mature 'Loring' and 'Redhaven' peach trees grown with ground cover competition. Within each cultivar, bars with the same letter do not differ at $P \leq 0.05$. 
tial of each tree was measured at a height of $\approx 2$ m at least once each month during the 1996 , 1997, and 1998 growing seasons. Measurements were taken for one replicate of all treatments at dawn on one day and all trees of each cultivar were measured within 1 week. A leaf was covered with aluminum foil, the petiole was cut, and water potential was measured immediately with a pressure chamber (Soil Moisture Equipment Corp., Santa Barbara, Calif.). In August of each year, 20 leaves per tree were collected from current year shoots, pooled, dried for three days at $80{ }^{\circ} \mathrm{C}$, and ground to pass a 10-mesh screen. Leaf $\mathrm{N}$ concentrations was measured with a Nitrogen Determinator (model FP228; LECO Corp., St. Joseph, Mich.).

Grass and weed abundances. Ground area covered by weeds and grass was estimated in Sept. 1995, 1996, and 1997, as the average of visual estimates by two people. In addition, each plot was divided into four equal areas and a $250-\mathrm{cm}^{2}$ quadrat was randomly placed in each area. The number and weight of grass seedlings and the weight of weed seedlings were measured in each quadrat to provide estimates of plant density.

\section{Results and Discussion}

Vegetative growth, yield, and pruning. All grass and weedy treatments reduced vegetative growth and yield compared to herbicide treatments but some grasses were more inhibitory than others (Figs. 1 and 2). Orchardgrass and red top were among the more inhibitory grasses while brome and 'Linn' ryegrass were among the least inhibitory to peach tree growth and yield (Figs. 1 and 2). Compared to herbicide treatments, orchardgrass and red top reduced vertical shoot length by $\approx 25 \%$ in 'Loring' and $15 \%$ in 'Redhaven'. Orchardgrass had a large impact on fruit yield, reducing yield by $37 \%$ and $24 \%$ in 'Loring' (predominantly in the 50.8 to $63.5 \mathrm{~mm}$ size class) and 'Redhaven' (predominantly in the $>63.5 \mathrm{~mm}$ size class), respectively (Fig. 3). 'Manhattan' ryegrass was competitive, especially in 'Loring'. Lateral shoot length was reduced the most with 'Manhattan' ryegrass by 33\% in 'Loring' and $19 \%$ in 'Redhaven'. Tall fescue was intermediate in competitiveness and timothy suppressed yield but not vegetative growth. The weedy control and brome grass not differ from the herbicide treatment in affecting peach tree growth or yield.

Yield efficiency was reduced by Manhattan ryegrass and timothy in 'Loring' and by red top grass in 'Redhaven' trees (Fig. 2). Glenn and Welker (1996) reported reduced yield, but not yield efficiency, with sod beneath 3-year-old peach trees. In this study, yield was reduced at least as much as vegetative growth, so that yield efficiency remained unchanged or decreased slightly. Although yield efficiency in 'Redhaven' generally was not reduced by grass (compared to herbicide treatment), the fruit yield in the largest size class $(>63.5 \mathrm{~mm})$ was reduced by five of the grasses, indicating a potentially negative economic impact (Figs. 2 and 3). In 'Loring' most

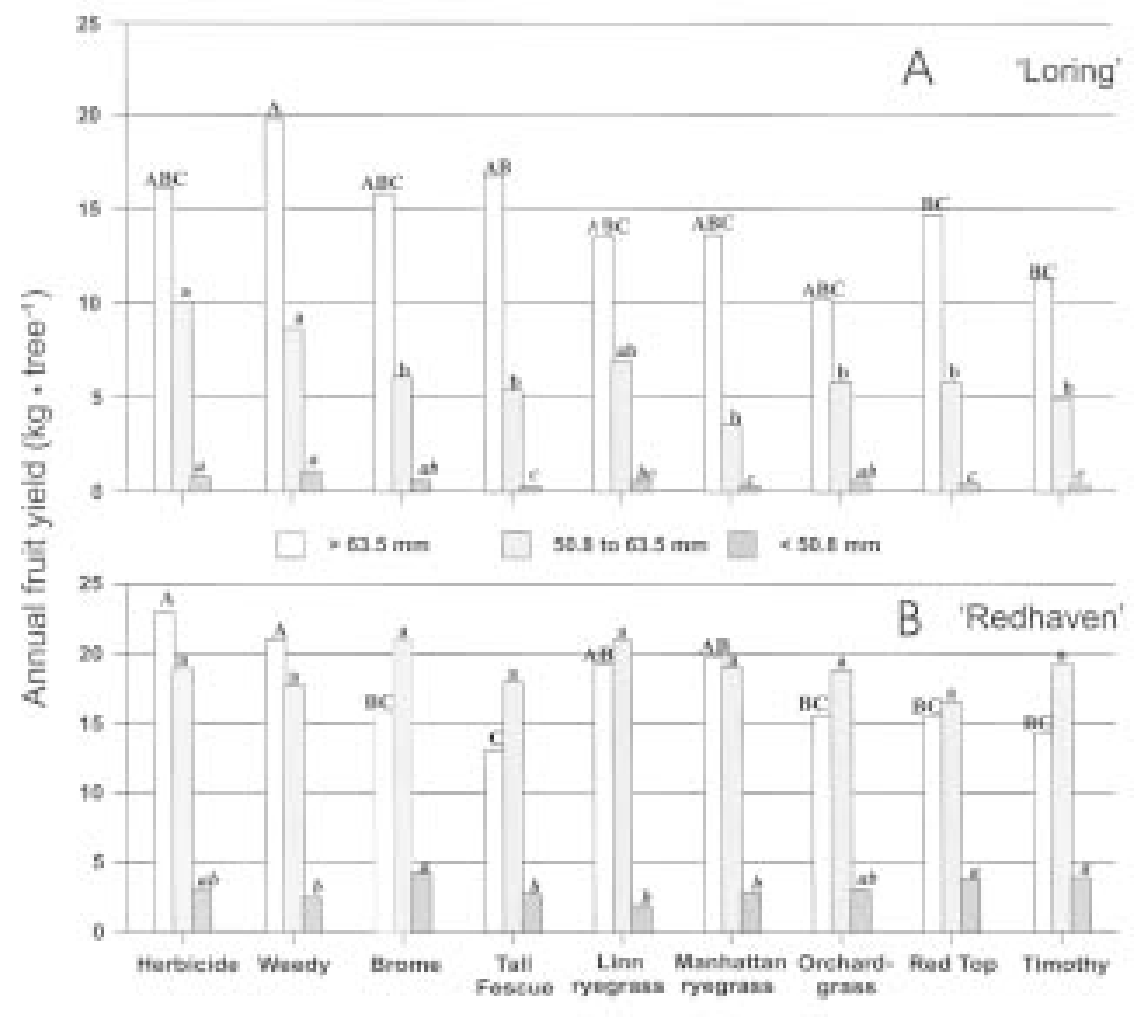

Fig. 3. Average weight of fruit per tree (1995-98) for three size classes of peaches harvested each year from mature (A) 'Loring' and (B) 'Redhaven' peach trees grown with ground cover competition. Within each cultivar and size class, bars with the same letter do not differ at $P \leq 0.05$.

yield reduction occurred in the intermediate and small size classes. Thinning of 'Redhaven' may have reduced grass effects on yield of the large size fruit since 'Redhaven' had high fruit set (400 fruit per tree per year vs. 242 fruit in

'Loring'.

Pruning weights were reduced by fescue and orchardgrass for 'Redhaven', and in 'Manhattan' ryegrass, orchardgrass, red top grass, and weedy for 'Loring' (Fig. 4), following
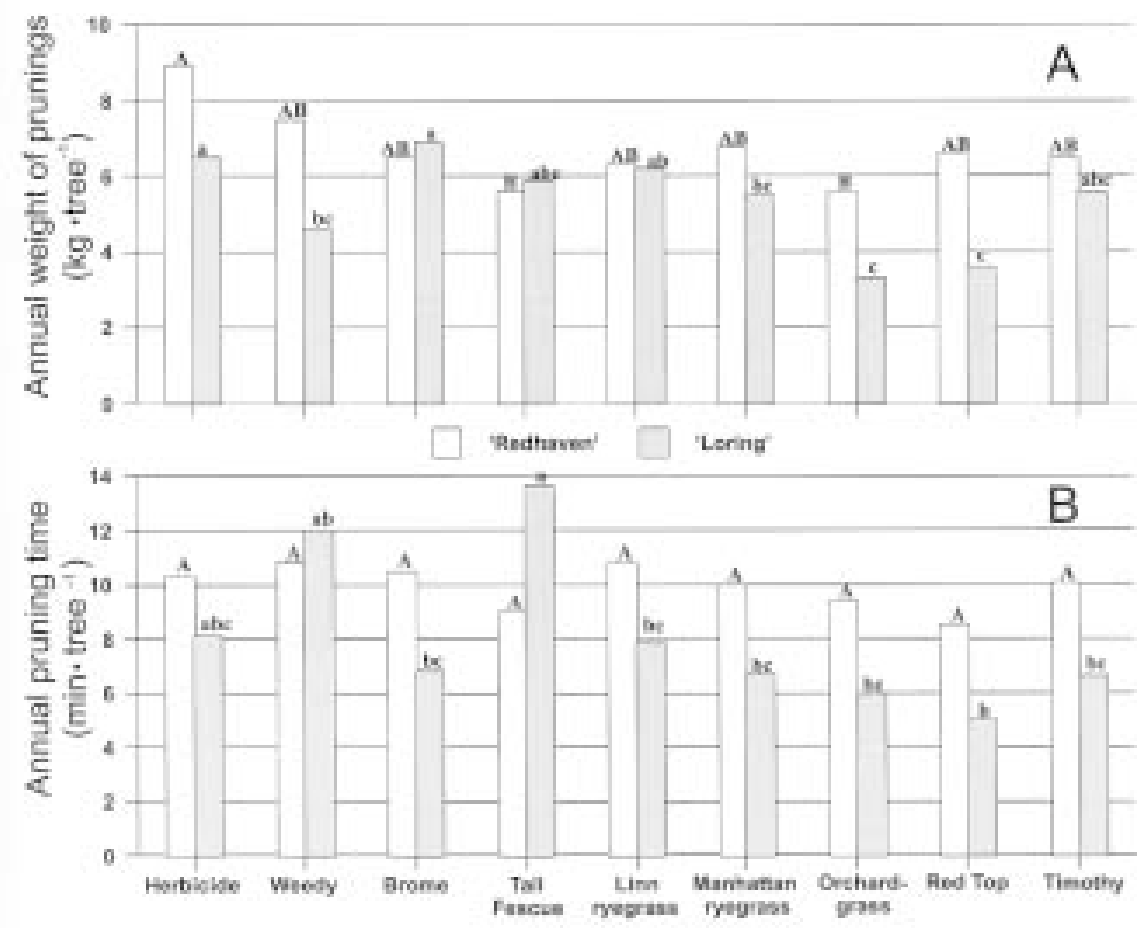

Fig. 4. (A) Average annual weight of pruned shoots and (B) time for pruning per tree (1995-97) for mature 'Loring' and 'Redhaven' peach trees grown with ground cover competition. Within each cultivar, bars with the same letter do not differ at $P \leq 0.05$. 
similar trends as shoot growth. As with vegetative growth and yield, orchardgrass caused among the greatest reductions in pruning weights in 'Loring' and 'Redhaven'. However, weight of pruned shoots was not significantly correlated with pruning time (data not shown). Grass-induced reduction of tree growth and pruning weights did not translate to reduced pruning time (Fig. 4). Therefore, benefits to growers using managed grass competition with mature peach trees may come from reduced tree size or selective weed control.

The fact that fewer statistical differences than expected were found between herbicidetreated plots and grassed plots may be due to variation among plots caused by differences in edaphic conditions. To account for the effect of soil factors, topsoil depth was measured and used as a covariable in statistical analyses. However, no additional differences were found using analysis of covariance with soil depth as the covariable. Significant reductions in growth and yield due to grass may have been detected if other edaphic factors were characterized as sources of variation.

Physiological indices and root growth. Grass and weeds did not affect peach tree leaf water potential (data not shown). Evidently, mature peach trees were able to obtain adequate water even with grass competition. When maintained in weed-free alleys, trees exploit more of the grassed areas as they age (Atkinson, 1980). Mature trees used in this experiment likely had root growth to greater depths than grass and therefore, they were less susceptible to competition for water than younger peach trees which are relatively more suppressed by grass competition (Glenn and Welker, 1996). Peach fruit weights may increase with irrigation when trees experience grass competition for water or when exposed to prolonged drought. It would also be useful to further study the impact of grasses on midday water potential and carbon assimilation of peach trees. However, under average climatic conditions during the 3 years of this experiment in West Virginia, peach tree predawn water status was not affected by grass.

Although peach root density was reduced in the top $20 \mathrm{~cm}$ of soil when grass was present (Table 1), grass did not influence predawn water status in peach trees. Atkinson (1980) reported that apple tree root systems under grass were wider, more branched, with increased fine root weight and decreased larger root weight at all depths. Such morphological changes may reflect a tree competing with grass for limiting resources (i.e. exploiting more soil volume). In the current experiment, both root density and specific root length of peach trees decreased when trees were grown with ground cover competition (Table 1). This corroborates a previous study in which grass reduced peach tree root weight at depths from 0 to $30 \mathrm{~cm}$ (Tworkoski, 2000). However, in that study, grass did not affect tree root weight at depths below $30 \mathrm{~cm}$. Adequate root growth below $30 \mathrm{~cm}$ should enable the tree to absorb water from depths where grass root density decreases. Peach root density decreased only $36 \%$ but grass root density decreased $79 \%$ from the 0 to $10 \mathrm{~cm}$ to the 10 to $20 \mathrm{~cm}$ depths (Table 1).

Grasses and weeds consistently reduced peach tree leaf $\mathrm{N}$ by at least $10 \%$ compared to herbicide treatment in 'Redhaven' (Fig. 5). However, 'Loring' was less affected. Competition by grass reduced $\mathrm{N}$ in fruit trees in previous experiments (Hogue and Neilson, 1987). Peach trees may become $\mathrm{N}$-deficient when leaf $\mathrm{N}$ concentrations are $<2.5 \%$ (Childers et al., 1995). Tworkoski et al. (1997) found that increased grass competition resulted in higher percentage of $\mathrm{N}$ partitioned to stems and leaves and less to fruit of peach trees. Since grass competition appeared to inhibit yield more than vegetative growth, $\mathrm{N}$ may become limiting for fruit production when peach trees are grown with grass covers. However, other minerals could also limit fruit pro- duction. In pecan, Goff et al. (1991) reported that leaf concentrations of $\mathrm{N}, \mathrm{P}, \mathrm{B}, \mathrm{Cu}$, and $\mathrm{Fe}$ were not significantly affected by weeds but that $\mathrm{K}, \mathrm{Ca}$, and $\mathrm{Mg}$ were reduced by weed competition.

Grass and weed abundances. Weed abundance was reduced by grasses regardless of grass shoot or root density (Fig. 6). In previous research we observed red top and ' $\mathrm{K}-31$ ' tall fescue had large root systems, growing to $1-\mathrm{m}$ depths (Tworkoski and Glenn 1996). Roots of perennial ryegrass also grew to 1-m depths, but were smaller than tall fescue, and brome grass roots grew to the least depth. Root depth may be partly responsible for grass competitiveness.

Grass density varied by species, but all grasses reduced weed weight (Fig. 6). Tall fescue and orchardgrass provided among the best weed control. Correlation coefficients between grass weight and weed weight and pruning weight were -0.33 . Merwin and Ray (1997) proposed that soil benefits of limited weed control such as increased organic matter decreased erosion and improved water retention and should be weighed against yield losses in apple orchards. In this experiment, grasses (orchardgrass, for example) that were most inhibitive to peach yield also were most inhibitive to weed growth. However, even the less competitive grasses (e.g. brome) significantly reduced broadleaved weeds and crabgrass, suggesting that grass cover beneath peach trees may be a viable tool to manage the weed community in fruit orchards.

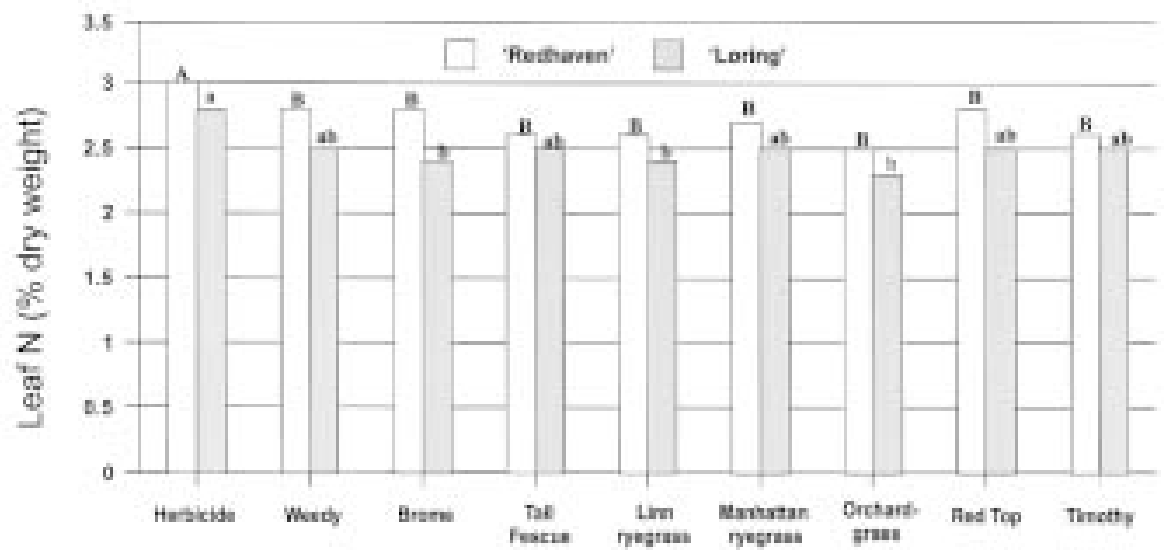

Fig. 5. Leaf N concentration of mature 'Loring' and 'Redhaven' peach trees grown with ground cover competition (1995-97). Within each cultivar, bars with the same letter do not differ at $P \leq 0.05$.

Table 1. Root characteristics of 12-year-old 'Redhaven' peach trees and ground covers in 1998 after four years of growing together.

\begin{tabular}{|c|c|c|c|c|c|c|c|c|}
\hline \multirow[b]{3}{*}{ Ground cover } & \multicolumn{4}{|c|}{0 -to-10 cm depth } & \multicolumn{4}{|c|}{ 10-to-20 cm depth } \\
\hline & \multicolumn{2}{|c|}{ Root density $\left(\mathrm{cm} \cdot \mathrm{cm}^{-3}\right)$} & \multicolumn{2}{|c|}{ Specific root length $\left(\mathrm{cm} \cdot \mathrm{gm}^{-1}\right)$} & \multicolumn{2}{|c|}{ Root density $\left(\mathrm{cm} \cdot \mathrm{cm}^{-3}\right)$} & \multicolumn{2}{|c|}{ Specific root length $\left(\mathrm{cm} \cdot \mathrm{gm}^{-1}\right)$} \\
\hline & Peach & Ground cover & Peach & Ground cover & Peach & Ground cover & Peach & Ground cover \\
\hline Herbicide & $11.7 \mathrm{a}$ & --- & $2106 \mathrm{a}$ & --- & $4.1 \mathrm{a}$ & --- & 1333 & --- \\
\hline Weedy & $1.0 \mathrm{~b}$ & 8.1 & $459 \mathrm{~b}$ & 1793 & $0.7 \mathrm{~b}$ & 2.7 & 902 & 1979 \\
\hline Brome & $1.4 \mathrm{~b}$ & 20.0 & $758 \mathrm{~b}$ & 4490 & $1.2 \mathrm{~b}$ & 7.3 & 1154 & 3878 \\
\hline Fescue & $0.7 \mathrm{~b}$ & 35.4 & $675 \mathrm{~b}$ & 3870 & $0.5 \mathrm{~b}$ & 4.4 & 665 & 3068 \\
\hline Linn & $1.5 \mathrm{~b}$ & 33.3 & $590 \mathrm{~b}$ & 4328 & $0.5 \mathrm{~b}$ & 4.2 & 720 & 4060 \\
\hline Manhattan & $1.4 \mathrm{~b}$ & 40.8 & $490 \mathrm{~b}$ & 4080 & $0.7 \mathrm{~b}$ & 9.5 & 220 & 4801 \\
\hline Orchardgrass & $0.8 \mathrm{~b}$ & 28.2 & $607 \mathrm{~b}$ & 3595 & $0.5 \mathrm{~b}$ & 6.8 & 659 & 3767 \\
\hline Redtop & $1.2 \mathrm{~b}$ & 17.6 & $674 b$ & 2100 & $0.8 \mathrm{~b}$ & 4.8 & 830 & 2331 \\
\hline Timothy & $0.8 \mathrm{~b}$ & 29.0 & $745 \mathrm{~b}$ & 4262 & $0.6 \mathrm{~b}$ & 4.0 & 966 & 3787 \\
\hline
\end{tabular}

Within each column, means followed by the same letter do not differ at $P \leq 0.05$. In columns that have no letters following means, ground cover treatments were nonsignificant. 


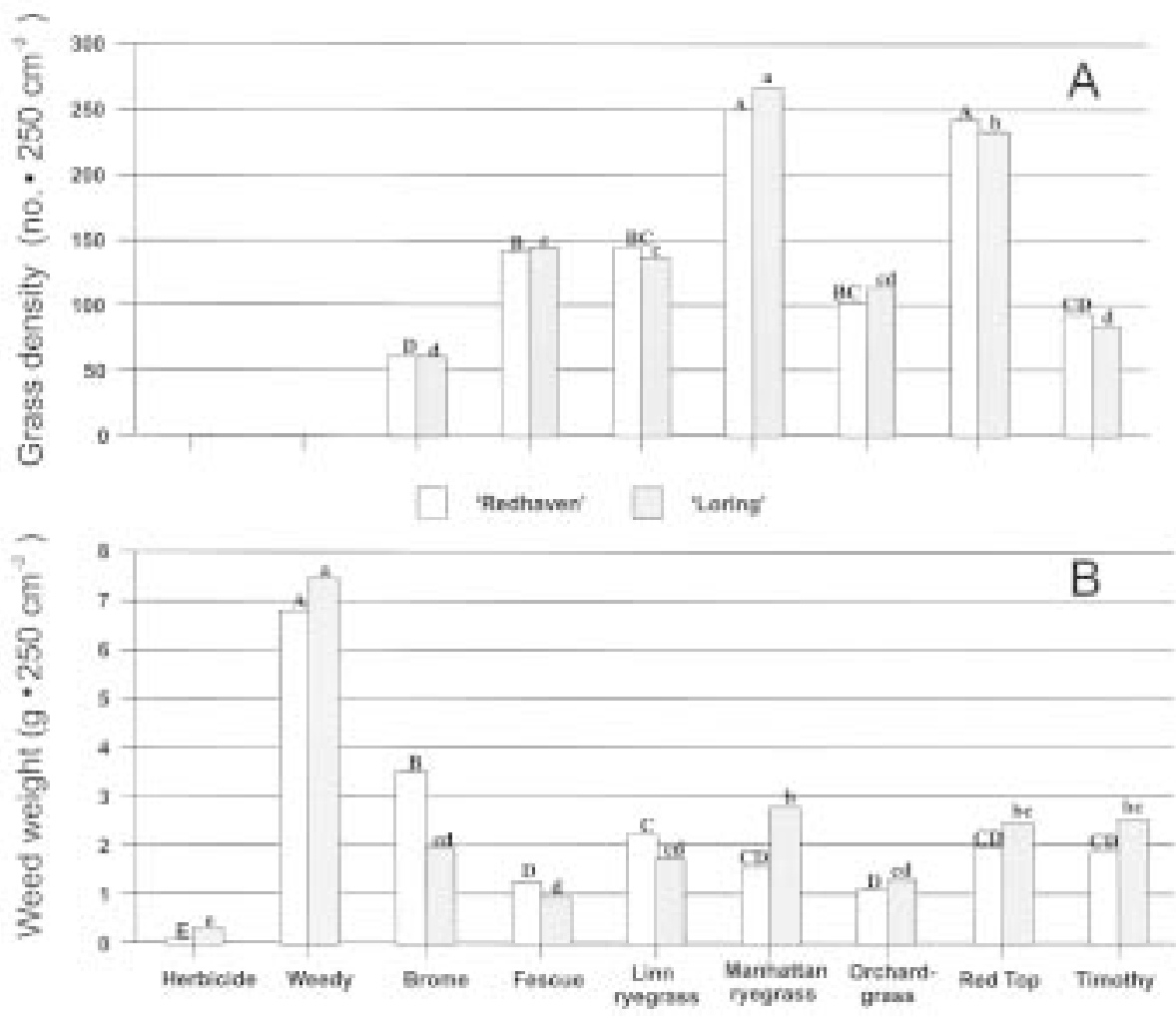

Fig. 6. (A) Average annual grass density and (B) weed weights in plots of mature 'Loring' and 'Redhaven' peach trees grown with ground cover competition (1995-97). Within each cultivar, bars with the same letter do not differ at $P \leq 0.05$.

Peach cultivars responded differently to grass competition, but the relative competitiveness of grass species was similar for both cultivars. Some grass species reduced growth of mature peach trees, but this reduction did not translate to reduced pruning time per tree. In this experiment, grass competition reduced leaf $\mathrm{N}$ but not leaf water potential, which may be due to grasses more effectively exploiting the shallower, more fertile soil layers as opposed to deeper layers having low $\mathrm{N}$ fertility but more water. In several ground cover treatments, fruit yield appeared to be reduced more than vegetative growth. Soil $\mathrm{N}$ therefore appeared to be more limiting than soil water, and fruit yield was more sensitive than vegetative growth to reduced $\mathrm{N}$. One distinct benefit of grass cover was suppression of weeds and, consequently, grasses may reduce pathogens
Butler, J.D. 1986. Grass interplanting in horticulture cropping systems. HortScience 21:394-396.

Childers, N.F., J.R. Morris, and G.S. Sibbett. 1995. Modern fruit science. Hort. Publ., Gainesville, Fla.

Glenn, D.M. and W.V. Welker. 1996. Sod competition in peach production: I. Managing sod proximity. J. Amer. Soc. Hort. Sci. 121:666-669.

Goff, W. D., M. G. Patterson, and M. S. West. 1991. Orchard floor management practices influence elemental concentrations in young pecan trees. HortScience 26:1379-1381.

Hayden, R.A. and F. H. Emerson. 1975. Summer pruning the peach, p. 263-269. In: N.F. Childers, (ed.). The Peach. Hort. Pub., New Brunswick, N.J.

Haynes, R.J. 1980. Influence of soil management practice on the orchard agro-ecosystem. Agro-Ecosystems 6:3-32.

Hipps, N.A., M.S. Ridout, and D. Atkinson. 1990. Effects of alley sward width, irrigation, and nitrogen fertilizer on growth and yield of Cox's Orange Pippin apple trees. J. Sci. Food and Agr. 53(2):159-168

Hill, R.G. 1962. The effect of sod as a soil management practice upon the growth and yield of the peach. Ohio Agr. Expt. Sta. Res. Bul. 903, Wooster.

Hogue, E.J. and G.H. Neilsen. 1987. Orchard floor vegetation management. Hort. Rev. 9:377-430.

Huslig, S.M., M.W. Smith, and G.H. Brusewitz. 1993. Irrigation schedules and annual ryegrass as a ground cover to conserve water and control peach tree growth. HortScience 28:908-913.

Merwin, I.A. and W.C. Stiles. 1998. Integrated weed and soil management in fruit plantings. Cornell Coop. Ext. Bul. 242.

Merwin, I.A. and J.A. Ray. 1997. Spatial and temporal factors in weed interference with newly planted apple trees. HortScience 32:633-637.

SAS Institute. 1994. SAS/STAT user's guide, Release 6. SAS Inst., Cary, N.C.

Shribbs, J.M., W.A. Skroch, and T.J. Monaco. 1986 Interference between apple (Malus domestica) seedlings and four ground cover species under greenhouse conditions. Weed Sci. 34:533-537.

Tworkoski, T.J. 2000. Response of potted peach trees to pruning and grass competition. HortScience 35:1209-1212.

Tworkoski, T.J. and D.M. Glenn. 1996. Evaluation of ground covers for peach orchard management using a bean bioassay, p. 42-51. In: R.F. Heflebower (ed.). Proc. of the 72nd CumberlandShenandoah Fruit Worker Conf., Winchester, Va.

Tworkoski, T.J., D.M. Glenn, and W.V. Welker. 1997. Carbohydrate and nitrogen partitioning within one-year shoots of young peach trees grown with grass competition. HortScience 32:1174-1177. 